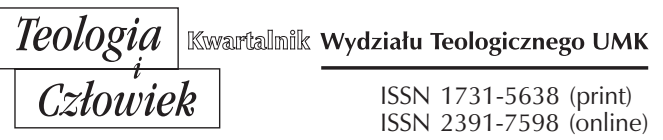

(c) (1) $\odot$

54(2021)2, ss. 45-61

KS. MAREK SKIERKOWSKI

UNIWERSYTET KARDYNAŁA STEFANA WYSZYŃSKIEGO W WARSZAWIE

M.SKIERKOWSKI@UKSW.EDU.PL

ORCID: 0000-0002-3513-7264

\title{
JEZUS W POCZĄTKOWEJ FAZIE JUDAIZMU NAUKOWEGO
}

DOI: http://dx.doi.org/10.12775/TiCz.2021.010

Streszczenie. Artykuł dotyczy początkowej fazy judaizmu naukowego w relacji do Jezusa. W XIX wieku niektórzy europejscy Żydzi przerwali swoje tradycyjne milczenie o najważniejszej ziemskiej postaci chrześcijaństwa. Przede wszystkim zaczęli oni czytać Nowy Testament, traktując go w kategoriach niezbędnego źródła na tym polu. Odkryli, że Jezus był prawdziwie żydowski. Niektórzy z nich (I.M. Jost, M. Zipser, L. Philippson, I.M. Rabbinowicz, A. Geiger, H. Rodrigues, M. Duschak, E. Grünebaum, M. Güdemann, A.A. Weill, E. Soloweyczyk, S. Hirsch) umieścili Go w centrum judaizmu, nawet jako faryzeusza, a niektórzy (J.L. Saalschütz, H. Graetz, J. Hamburger, E. Benamozegh, K. Magnus) ulokowali Go na obrzeżach judaizmu, np jako esseńczyka. W ten sposób chrześcijańska apologia, zwana tradycyjnie "Contra/Adversus Judaeos", zyskała nowy konstruktywny i dynamiczny początek.

Słowa kluczowe: apologia; dialog; Jezus; judaizm.

Abstract. Jesus in the initial phase of the science of Judaism. The article deals with the initial phase of the Science Judaism in relation to Jesus. In the nineteenth Century some European Jews broke their traditional silence about the most important earthly figure of Christianity. First of all they began to reading the New Testament, treating it in the terms of indispensable source in this field. They discovered that Jesus was truly Jewish. Some of them (I.M. Jost, M. Zipser, L. Philippson, I.M. Rabbinowicz, A. Geiger, H. Rodrigues, M. Duschak, E. Grünebaum, M. Güdemann, A.A. Weill, E. So- 
loweyczyk, S. Hirsch) place Him in the central Judaism, even as a Pharisee, some of them (J.L. Saalschütz, H. Graetz, J. Hamburger, E. Benamozegh, K. Magnus) located Him in edge of Judaism, for instance as an Essenic. In this way Christian Apology called traditionally „Contra/Adversus Judaeos” gained a new constructive and dynamic beginning.

Keywords: Apology; dialogue; Jesus; Judaism.

Niejako rewersem trwających w nowożytnej Europie żydowskich procesów emancypacyjnych była próba uformowania naukowej wersji judaizmu, po niemiecku Wissenschaft des Judentums, a po angielsku Science of Judaism. Znak rozpoznawczy tego przedsięwzięcia stanowiła intuicja filologa Leopolda Zunza (Yoma Tova Lippmanna; 1794-1886), polegająca na traktowaniu literatury żydowskiej jako integralnej część całej kultury ludzkiej ${ }^{1}$. Jednocześnie oznaczało to odważniejsze sięganie po Nowy Testament, który dotyczył przecież także pewnego okresu w historii Żydów.

W niniejszym opracowaniu chodzi o panoramiczne uchwycenie specyfiki żydowskiego spojrzenia na Jezusa w początkowej fazie judaizmu naukowego. Ta właśnie „początkowość” pozwoli na odkrycie, z jakim rodzajem oddziaływania na wyznawców judaizmu mamy do czynienia w sytuacji sięgnięcia przez nich po Nowy Testament, odczytywany zasadniczo po raz pierwszy w historii bez tradycyjnego uprzedzenia, że można zaznać skażenia bezbożną herezją. Dotychczas bowiem Żydzi albo dobrowolnie ograniczali się do Jezusa zaprezentowanego w Talmudzie, albo byli misyjnie przymuszani przez Kościół do słuchania chrześcijańskich polemistów ${ }^{2}$. Po Nowy Testament sięgali raczej sporadycznie i ostrożnie.

1 Por. N.N. Glatzer, G. Pelger, Zunz, Leopold, w: Encyclopaedia Judaica, red. F. Skolnik, M. Berenbaum, Detroit i in. 2007, wyd. II, t. 21, s. 684-688.

${ }^{2}$ Warto nadmienić, że Joseph Salvador (1796-1873) jest autorem pierwszej książki napisanej z perspektywy żydowskiej i w całości poświęconej Jezusowi, aczkolwiek ignorowanej z tej racji, że sam urodził się z matki katoliczki, a ostatecznie kazał pogrzebać się na cmentarzu protestanckim. Dwutomowe dzieło (Jesus-Christ et sa doctrine: histoire de la naissance de l'église, de son organisation et de ses progrès pendant le premier siècle, Paris 1838) prezentowało Jezusa jako człowieka wiążącego myśl żydowską z orientalną doktryną o zmartwychwstaniu, przyniesioną do Ziemi Izraela przez Żydów powracających z wygnania do Babilonii (i Persji). 
Kim zatem tożsamościowo okazał się żydowski Jezus dla światlejszych wyznawców judaizmu żyjących w Europie XIX wieku?

\section{NEGACJA HISTORYCZNOŚCI JEZUSA}

Prawdopodobnie w połowie XIX wieku w Londynie ukazała się anonimowo i bez podania roku książka The Existence of Christ Disproved By Irresistible Evidence, In A Series of Letters, From A German Jew. [30 Letters]. Jesus Christ. Jak sam tytuł wskazuje, „niemiecki Żyd”, pisząc trzydzieści listów adresowanych do chrześcijan rozmaitych denominacji, neguje historyczną egzystencję Jezusa. Akceptować ją mogą bowiem tylko fanatycy (którzy z natury rzeczy nie posługują się rozumem), niewolnicy (którzy nie mają odwagi posługiwać się rozumem) i głupcy (którzy nie są w stanie posługiwać się rozumem) $)^{3}$.

Michael Kulisher (1847-1919), historyk, etnograf i działacz społeczny, który uczył się w rabinicznym seminarium w Żytomierzu (dziś Ukraina) i studiował prawo na Uniwersytecie w Sankt Petersburgu, a w latach 1869-1871 był redaktorem gazety Żydów rosyjskich „Den”, także zanegował historyczną egzystencję Jezusa ${ }^{4}$. Jego zdaniem, u źródeł stworzenia mitu Jezusa tkwi idea zbożowego snopa ofiarowanego w świątyni jerozolimskiej; w ten sposób mityczny Jezus uczy ludzi po prostu takiego dojrzewania w życiu (np. Jego chrzest to nawodnienie gleby deszczem $\mathrm{z}$ nieba ${ }^{5}$ ), by $\mathrm{w}$ momencie śmierci wydali oni plon doskonałej miłości (por. Mt 20,28) . $^{6}$

Naukowy judaizm stara się także zweryfikować dane Talmudu o Jezusie. Joseph (Neftali) Derenbourg (1811-1895), żydowski orientalista (urodzony we Francji, a zmarły w Niemczech) przyznawał (aczkolwiek

3 Por. [Anonimowo] The Existence of Christ Disproved By Irresistible Evidence, In A Series of Letters, From A German Jew. [30 Letters]. Jesus Christ, London [bez roku wydania], s. 98.

${ }^{4}$ Por. M. Kulisher, Das Leben Jesu eine Sage von dem Schicksale und Erlebnissen der Bodenfrucht, insbesondere der sogenannten palästinensischen Erstlingsgarbe, die am Passahfeste im Tempel dargebracht wurde, Leipzig 1876, s. 3.

5 Por. tamże, s. 38-39.

${ }^{6}$ Por. tamże, s. 110. 
nie on pierwszy w historii), że Jezus chrześcijan i Ben Stada z literatury rabinicznej nie są źródłowo tożsami ${ }^{7}$ Z kolei Manuel Joël (zm. 1890), rabin z Wrocławia (Breslau), jakby dopowiadał, że twórcy judaizmu pobiblijnego tak bardzo skoncentrowali się na egzegezie Biblii, celem jej zaktualizowania w nowej sytuacji po zburzeniu świątyni jerozolimskiej (70 r.), że w ogóle nie interesowali się czymkolwiek innym, w tym także wydarzeniami z życia Jezusa; kiedy zaś w II wieku chrześcijaństwo wyodrębnia się już jako heretycka w stosunku do judaizmu religia, rabini są w stanie jedynie polemicznie pospekulować o Jezusie na bazie swojej literatury ${ }^{8}$.

\section{JEZUS W CENTRUM JUDAIZMU}

W XIX wieku pojawili się uczeni żydowscy, którzy doszli do przekonania, że Jezusa można umieścić niejako w samym centrum judaizmu Drugiej Świątyni, a nawet jako, formalnie bądź nieformalnie, faryzeusza.

Isaac Marcus Jost (1793-1860), który pracował w różnych ośrodkach edukacyjnych Frankfurtu nad Menem, jest pionierem nowożytnej historiografii żydowskiej ${ }^{9}$. W latach 1820-1928 wydał w Berlinie dziewięciotomową Geschichte der Israeliten seit der Zeit der Maccabäer bis auf unsere Tage nach den Quellen bearbeitet, odnosząc się w jednym rozdziale do „powstania chrześcijańskiej religii”" ${ }^{10}$, traktując Jezusa jako Żyda o głębokim umyśle, który chciał zerwać ze skostniałym legalizmem uczonych faryzejskich; oni właśnie za pośrednictwem Sanhedrynu wymusili na Piłacie zgładzenie Jezusa, celem umocnienia swoich dotychczasowych wpływów ${ }^{11}$.

7 Por. J. Derenbourg, Essai sur l'Histoire et la Géographie de la Palestine, d'après les Thalmuds et les autres sources rabbiniques, I: Histoire de la Palestine depuis Cyrus Jusqu'à Adrien, Paris 1867, s. 201-204, 468-471.

8 Por. M. Joël, Blicke in die Religionsgeschichte zu Anfang des zweiten christlichen Jahrhunderts mit Berücksichtigung der angränzenden Zeiten. II. Abtheilung: Der Conflict des Heidenthums mit dem Christenthume in seinem Folgen für das Judenthum, Breslau 1883, s. 54-58.

${ }^{9}$ Por. M. Pyka, Jost, Isaac Marcus, w: Encyclopaedia Judaica, t. 11, s. 463-464.

${ }^{10}$ I.M. Jost, Geschichte der Israeliten seit der Zeit der Maccabäer bis auf unsere Tage nach den Quellen bearbeitet, Berlin 1820, t. I, s. 295-300.

11 Por. tamże, s. 298. 
Pod koniec swojego życia I.M. Jost wydał trzytomową Geschichte des Judenthums und seiner Sekten (1857-1859), poświęcając jeden rozdział "powstaniu chrześcijaństwa”12, jeden „skazaniu i ukrzyżowaniu Jezusa”13 i jeden „judeochrześcijanom" ${ }^{14}$. Ponownie podkreśla ogromny wpływ Jezusa na masy niewykształconych ludzi, które oczekiwały reformatorskiej odnowy judaizmu ${ }^{15}$. Jego śmierć nie stanowiła wyniku żadnego legalnego sądu żydowskiego, lecz była po prostu „prywatnym mordem” (Priwatmord), dokonanym z inicjatywy arcykapłana Kajfasza i wskutek decyzji pozbawionego silnego charakteru Piłata; ogólnie rzecz biorąc, Jezusa doprowadziła do śmierci „bliżej nieokreślona liczba Jego aroganckich wrogów"16.

Kilku uczonych podjęło się porównania Jezusowego Kazania na Górze (Mt 5-7 i par.) z literaturą rabiniczną. Maier Zipser (1815-1869), Żyd węgierski, rabin najpierw w Białogrodzie Królewskim, a potem w Rechnitz (wtedy węgierski Rohonc/Rohoncz, dziś Austria), jest zdania, że Jezus uwypuklił jedynie najwspanialsze, znane ze szkół faryzejskich, nauczanie żydowskie, sprzeciwiając się nadużyciom, na które ówczesne autorytety intelektualne mogły jeszcze nie zwracać uwagi, ale późniejszy Talmud już je potępi; zatem „wszystkie moralne zalecenia, przypowieści i nakazy etyczne zawarte w Ewangelii" ${ }^{17}$ były wpajane przez żydowskich doktorów „albo żyjących przed Założycielem chrześcijańskiej religii, [...] albo na odległych terytoriach"18. Hippolyte Rodrigues (1812-1898), Żyd francuski, bankier i pisarz, ukazywał, werset po wersecie, paralelność Jezusowego Kazania na Górze wobec uprzednich źródeł żydowskich ${ }^{19}$, opowiadając się także ogólnie za zgodnością nauczania Jezusa z doktryną

${ }_{12}$ I.M. Jost, Geschichte des Judenthums und seiner Sekten, t. I, Leipzig 1857, s. $394-402$.

13 Por. tamże, s. 402-409.

14 Por. tamże, s. 409-418.

15 Por. tamże, s. 400.

16 Tamże, s. 408.

17 M. Zipser, The Sermon on the Mount Reviewed in an Essay on the Talmud and the Gospels, London 1852, s. 3-4.

18 Tamże, s. 23.

19 Por. H. Rodrigues, Les Origines du Sermon de la Montagne, Paris 1868, s. $20-117$. 
Hillela ${ }^{20}$. Wreszcie Moritz (Mordechaj) Duschak (1815-1890), światły rabin, który działał m.in. w Krakowie (Galicja; lata 1877-1888), optował za źródłowością (i w tym sensie nieprzemijalnością) etycznego nauczania rabinów talmudycznych w stosunku do wypowiedzi Jezusa ${ }^{21}$, jednocześnie uważał, że etyka Jezusowa może być ideałem tylko dla jakiejś wybranej grupy pobożnych wiernych ${ }^{22}$. Ponadto, Moritz Güdemann (zm. 1918), rabin wiedeński (od 1866 roku; wcześniej działał w Magdeburgu), wykazywał, że kluczowe dla chrześcijaństwa przykazanie miłości bliźniego wywodzi się całkowicie ze źródeł żydowskich; ewangelie zatem stanowią odbicie rabinicznych opinii swojego czasu, a to oznacza, że Jezus był wręcz talmudystą ${ }^{23}$.

Samuel Hirsch (1815-1889), który był rabinem w Dessau (18391941), a potem został głównym rabinem Wielkiego Księstwa Luksemburga (1843-1966), w końcu poproszono go o przyjęcie urzędu rabina w Filadelfii (USA), twierdził, że Jezus w swoim wnętrzu uchwycił ideę judaizmu i ją urzeczywistnił, ujmując „to, co stare, w pełnej istocie”24.

Ludwig Philippson (zm. 1889), w latach 1833-1862 rabin w Magdeburgu i założyciel „Allgemeine Zeitung des Judenthums” (1837) ${ }^{25}$, zauważał, że w momencie powstawania chrześcijaństwa dawny judaizm proroków przybrał formę przesadnego systemu prawnego, grawitując coraz wyraźniej ku „obłudnemu fanatyzmowi”26. Cale najpierwotniejsze

${ }^{20}$ H. Rodrigues, Le Roi des Juifs, Paris 1870, s. 59.

${ }^{21}$ Por. M. Duschak, Die Moral der Evangelien und des Talmuds: eine vergleichende Studie im Geiste unserer Zeit, Brünn 1877, s. IX-X.

${ }^{22}$ Por. tamże, s. 51-58.

${ }^{23}$ Por. M. Güdemann, Nächstenliebe. Ein Beitrag zur Erklärung des Matthäusevangeliums, Wien 1890, s. 29.

${ }^{24}$ S. Hirsch, Die Religionsphilosophie der Juden oder das Prinzip der jüdischen Religionsanschauung und sein Verhältni $\beta$ zum Heidenthum, Christenthum und zur absoluten Philosophie dargestellt und mit erläuterten Beweisstellen aus der heiligen Schrift, den Talmudim und Midraschim versehen, Leipzig 1842, s. 689.

${ }_{25}$ Por. Biographisches Handbuch der Rabbiner, red. M. Brocke, J. Carlebach, Teil 1: Die Rabbiner der Emanzipationszeit in den deutschen, böhmischen und großpolnischen Ländern 1781-1871, red. C. Wilke, München 2004, s. 702-706.

${ }^{26}$ L. Philippson, Die Entwickelung der religiösen Idee im Judenthume, Christenthume und Islam: in zwölf Vorlesungen über Geschichte und Inhalt des Judenthums dargestellt, Leipzig 1847, s. 102. 
chrześcijaństwo, z inspiracji Jezusa, stanowiło zatem „wysiłek zmierzający do przywrócenia wagi idei w stosunku do formy"27. L. Philippson wykazywał ponadto, że wiedza pewna o zgładzeniu Jezusa praktycznie pokrywa się ze wzmianką Tacyta, obciążającą jedynie władzę rzymską ${ }^{28}$.

Abraham Geiger (1810-1874) to jedna z największych postaci judaizmu XIX wieku. Urodził się we Frankfurcie nad Menem jako najmłodszy syn rabina, studiował w Heidelbergu i Bonn, doktoryzował się w Marburgu (1834) i otrzymał ordynację na rabina; piastował ten urząd kilka miesięcy w Hanau, a potem w Wiesbaden; założył „Wissenschaftliche Zeitschrift für jüdische Theologie”, pismo sponsorowane przez grupę szesnastu uczonych żydowskich; w 1840 roku objął urząd rabina w Breslau (Wrocław), gdzie istniała ponad pięciotysięczna wspólnota żydowska; pozostał tam do 1863 roku; był przeciwnikiem obrzezania („barbarzyński, krwawy akt”); wrócił do Frankfurtu, gdzie ukończył swoje kluczowe dzieło Das Judenthum und seine Geschichte (zapis oryginalny); w 1869 roku został wybrany na urząd rabina w Berlinie (przybywa do Berlina w styczniu 1870 roku $)^{29}$.

Zdaniem Geigera, jak islam miałby wywodzić się z judaizmu rabinicznego, tak chrześcijaństwo z judaizmu faryzejskiego. Judaizm w ogóle stanowi najczystszą ekspresję religii jako takiej, a faryzeusze byli samym jądrem ludu Bożego, Żydami par excellence. Najbliższą paralelą wobec Jezusa pozostaje pełen łagodnego humanizmu Hillel, rabbi działający u kresu ery przedchrześcijańskiej, który dokonał „odmłodzenia (Verjüngung) judaizmu” ${ }^{30}$. Jezus „był faryzejskim Żydem z galilejskim odcieniem”31, „był faryzeuszem, który szedł drogą Hillela”32. Jezus miał odwagę i pewność, by stwierdzić, że oto czas się wypełnił i nadeszło już królestwo niebieskie, spełniają się nadzieje mesjańskie ${ }^{33}$. Otaczali Go z początku

27 Tamże.

${ }^{28}$ Por. L. Philippson, Haben wirklich die Juden Jesum gekreuzigt?, Leipzig 1901 (pierwsze - Berlin 1866), s. 61.

29 Por. S. Heschel, Abraham Geiger and the Jewish Jesus, Chicago 1998, s. 24-49.

${ }^{30}$ A. Geiger, Das Judenthum und seine Geschichte. In zwölf Vorlesungen, Breslau 1864, s. 94.

\footnotetext{
31 Tamże, s. 111.

32 Tamże, s. 112.

33 Por. tamże, s. 114.
} 
niewykształceni i biedni Galilejczycy, skłonni do entuzjastycznych wierzeń apokaliptycznych $\mathrm{w}$ nastanie nowego świata; kiedy jednak potem Jego sława dotarła do Jerozolimy, został zgładzony; podstawą ukrzyżowania było to, że

zaingerował $\mathrm{w}$ religijne przekonania swojego czasu, wyniósł siebie na wysoką pozycję, która nie była odpowiednia dla Niego; reprezentował nadzieję przyszłości jako wypełnioną i wcieloną w sobie; głosił kompletną reformę wszystkich politycznych uwarunkowań, [...] chociaż faktycznie nie wzniecił rewolucji ${ }^{34}$.

Również Elias Grünebaum (zm. 1893), rabin z Landau (Niemcy), umieszcza Jezusa w obrębie faryzeizmu, ale rozumianego nie jako formalne ugrupowanie, lecz bardziej jako sposób na odnowę judaizmu, czyli „walki przeciwko pogaństwu w celu zachowania czystego monoteizmu i uzdrowienia całego ludu"35. Zasadnicza różnica między Jezusem i faryzeuszami polegałaby na tym, że gdy oni pozwalali na coś w sytuacji tylko konieczności, On zgadzał się na to w każdej sytuacji ${ }^{36}$.

Wreszcie Alexandre Abraham Weill (1811-1899), Żyd francuski, twierdził, że „wszystkie doktryny Jezusa były faryzejskie. [...] Jezus jedynie doprowadził te zasady logicznie do szczytu" ${ }^{37}$.

Warto w tym kontekście jeszcze nadmienić, że Elias (Elie, Elijah) Zvi/Zevi Soloweyczyk (Soloweitchik; 1805-1881), rabin litewski ze Słucka (dziś Białoruś), wydał w 1875 roku po francusku, sporządzony oryginalnie w języku hebrajskim, komentarz do Mt i Mk, zwracając się do chrześcijan jako swoich „braci” ${ }^{8}$ i twierdząc, że „istnieje namacalna zgodność między nauczaniem Synagogi i nauczaniem Nowego Testamentu"39.

${ }^{34}$ Tamże, s. 115.

${ }^{35}$ E. Grünebaum, Die Sittenlehre des Judenthums Anderen Bekanntnissen Gegenüber Nebst dem Geschichtlichen Nachweise über Enstehung des Pharisäismus und Dessen Verhältnis zum Stifter der Christlichen Religion, Mannheim 1867, s. 86.

36 Por. tamże, s. 125.

37 A.A. Weill, Moïse, le Talmud et l'Évangile, Paris 1891, s. 240.

38 Por. E. Soloweyczyk, Harvq Lvq Kol Koré (Vox clamantis). La Bible, le Talmud et l'Évangile. Évangile de Mathieu, Paris 1875, s. 17.

39 Tamże, s. 100. 


\section{JEZUS NA PERYFERIACH JUDAIZMU}

Niektórzy europejscy przedstawiciele judaizmu XIX wieku uznali wprawdzie żydowskość Jezusa, ale umieszczali Go na peryferiach tej religii, np. w gronie nieortodoksyjnych esseńczyków bądź traktowali tradycyjnie jako fałszywego Mesjasza.

Joseph Lewin Saalschütz (1801-1863), niemiecki rabin i uczony (archeolog), związany z Königsbergiem (polski Królewiec, dziś rosyjski Kaliningrad), szukał pojednania między judaizmem i chrześcijaństwem ${ }^{40}$, podkreślając żydowskość Jezusa w teologicznym sensie, a jednocześnie wiążąc Jego śmierć z dwoma zupełnie odrębnymi roszczeniami politycznymi: do bycia Synem Bożym i do bycia Mesjaszem; ten pierwszy tytuł „wprowadzał jakieś nowe Bóstwo”, ten drugi oznaczał niebezpieczne dla porządku społecznego inklinacje królewskie ${ }^{41}$. Podobnie Israel Michel Rabbinowicz (1818-1893), wykształcony syn rabina litewskiego, odbierał Jezusa jako w pełni żydowskiego, a jedyną Jego nowością były zgubne z perspektywy polityczno-ziemskiej roszczenia mesjańskie ${ }^{42}$.

Heinrich Graetz (oryginalnie Tzvi Hirsch Graetz; 1817-1891) to wybitny historyk żydowski, który urodził się w Książu Wielkopolskim (wtedy Prusy); uczył się u ortodoksyjnego rabina Samsona Raphaela Hirscha w Oldenburgu (1837-1840); studiował m.in. we Wrocławiu, a doktorat $\mathrm{z}$ filozofii uzyskał w Jenie (1845); przebywał jeszcze w kilku innych ośrodkach edukacyjnych (choćby w Berlinie), by ostatecznie podjąć wykłady z historii i krytyki biblijnej w Żydowskim Seminarium we Wrocławiu (od 1854 roku; tytuł profesora otrzymał w 1869 roku); poślubił Marię Monasch z Krotoszyna (1850); zmarł w Monachium, ale spoczął na Starym Cmentarzu Żydowskim we Wrocławiu ${ }^{43}$.

Jego jedenastotomowa Geschichte der Juden. Von den ältesten Zeiten bis auf die Gegenwart. Aus den Quellen neu bearbeitet (1853-1876)

${ }^{40}$ Por. J.L. Saalschütz, Zur Versöhnung der Confessionen, oder Judenthum und Christenthum, in ihrem Streit und Einklang, Königsberg 1844, s. 95.

${ }^{41}$ Por. J.L. Saalschütz, Das Mosaische Recht nebst der vervollständigenden thalmudisch-rabbinischen Bestimmungen. Für Bibelforscher, Juristen und Staatsmänner, t. II, Berlin 1853 (II wydanie), s. 624-625.

42 Por. J.M. Rabbinowicz, Le role de Jésus et des apotres, Bruxelles 1866, s. 31.

43 Por. S. Ettinger, M. Pyka, Graetz, Heinrich, w: Encyclopaedia, t. 8, s. 26-29. 
została doprowadzona do 1848 roku; historia Jezusa znajduje się w t. III; pominięto ją jednak w pierwszym wydaniu (Leipzig 1856), pojawiła się dopiero w wydaniu drugim (Leipzig 1862), a potem w trzecim (Leipzig 1878) i czwartym (Leipzig 1888, czyli ostatnim za życia autora). W 1862 roku przyjaciel Graetza, a mianowicie Moses Hess (zm. 1875), prekursor syjonizmu, w trakcie kilkumiesięcznego pobytu we Wrocławiu, zapoznał się $\mathrm{z}$ tezami Graetza o Jezusie i zrelacjonował je w dziele Rom und Jerusalem (1862), a konkretnie w epilogu, w paragrafie drugim zatytułowanym Christus und Spinoza ${ }^{44}$; Hess ponadto przetłumaczył fragment o Jezusie na język francuski i opublikował w Paryżu pod tytułem Sinai et Golgotha (1867).

Odnosząc się do Jezusa, Graetz zauważa, że

brak erudycji wetowały w Nim przymioty moralne. Zdobiły Go niewątpliwie cnoty wysokie i świętość żywota. [...] Przyrodzona skłonność musiała nieodzownie pociągnąć Jezusa do esseńczyków, którzy wiedli żywot kontemplacji oddany, obcy światu i jego próżnościom. Gdy więc Jan Chrzciciel, a raczej Esseńczyk, jął nawoływać do chrztu, do pokuty i gotowania królestwa Bożego, przyszedł doń Jezus i przyjął chrzest z rąk Jego. Acz nie przyjęty może formalnie do zakonu esseńskiego, przyswoił sobie niewątpliwie zasady esseńskie ${ }^{45}$.

Jezus nauczał nie cały naród, lecz tylko jego stan średni, ludowy, chcąc go „wyrwać z odrętwienia ciemnoty i występku”46. Jezusowy styl bycia podczas działalności publicznej można nazwać praktycznie „półesseńskim" ${ }^{47}$. Historyk żydowski przyznaje, że

na uświęcone zasady judaizmu nie porywał się Jezus bynajmniej, nie zamierzał wcale poprawić nauki żydowskiej lub w ogóle czegokolwiek nowego zakładać, pragnął jedynie przeistoczyć grzeszników w sprawiedliwych i zbożnych, aby uczynić ich godnymi doby mesjańskiej. Jedyność Boga podnosił $\mathrm{z}$ naciskiem $\mathrm{i}$ ani Mu w głowie powstało zmieniać właściwego judaizmowi pojęcia o Bóstwie ${ }^{48}$.

${ }^{44}$ Por. M. Hess, Rom und Jerusalem, wyd. II, Leipzig 1899, s. 113-134.

${ }^{45}$ Wydanie polskie: H. Graetz, Historja Żydów, tłum. S. Szenhak, Warszawa 1929, cz. 1/3, s. 541-542 (z drobnymi moimi udoskonaleniami językowymi).

46 Tamże, s. 543-544.

47 Tamże, s. 544.

48 Tamże, s. 545. 
Zdaniem Graetza, pod tym akurat względem Jezus bliski był kręgom faryzejskim: „Na podobieństwo Hillela uwewnętrzniał przepisy judaizmu, pojmował je duszą i sercem" 49 .

Zasadnicza zmiana w działalności kaznodziejskiej Jezusa nastąpiła pod Cezareą Filipową, gdzie „uczniowie poniekąd wydarli mu sami Jego tajemnicę"50; uznali Go bowiem za Mesjasza, chociaż On osobiście „nigdy nie mienił się Mesjaszem, lecz używał [...] wyrażeń niewątpliwie powszednich w kole esseńskim. Nazywał się synem człowieczym [...]. Innej jeszcze nazwy używał Jezus na określenie swego mesjanizmu, mianowicie fatalnego słowa syn Boży" ${ }^{11}$. Gdy mesjanizm Jezusa nie utrzymał się w dyskrecji uczniów, pojawiło się oczekiwanie ze strony ludzi, by Mesjasz zaprezentował się w Jerozolimie; i tam właśnie doszło do Jego skazania na śmierć przez Piłata pod zarzutem bycia „wichrzycielem i przestępcą stanu”52. Jak podsumowuje Graetz, myśląc o powstaniu religii chrześcijańskiej, ,jedyny to [był] mąż zrodzony z niewiasty, o którym bez przesady rzec można, że śmiercią swoją więcej zdziałał niż życiem. Golgota stała się dla świata dziejowego nowym Synajem"53.

Podobnie sądził rabin Jacob Hamburger (zm. 1911), który zasłynął nade wszystko ze stworzenia Real-Encyclopädie für Bibel und Talmud (inny tytuł: Encyclopädie des Judentums) ${ }^{54}$. Prawidłowo przyjmuje on priorytet Mk, twierdząc, że ewangelia ta ukazuje się ,jeszcze w pierwotnej, żydowskiej szacie”, gdy tymczasem J naznaczona jest już wyraźnie „aleksandryjską filozofią"; pozostałe zaś dwie ewangelie stanowią mieszaninę komponentów „żydowskich i greckich”"55. Jezus, tak jak Jan Chrzciciel, wyrósł z essenizmu ${ }^{56}$; głosił nadejście królestwa Bożego nie w ziemskim,

49 Tamże, s. 546.

50 Tamże, s. 547.

51 Tamże, s. 547-548.

52 Tamże, s. 551.

53 Tamże, s. 552.

54 Biographisches, t. 1, s. 409-411.

${ }^{55}$ J. Hamburger, Jesus von Nazaret. Geschichtliche, objektive Darstellung seines Lebens, Wirkens und Todes, Berlin 1895, s. 8.

${ }^{56}$ Por. tamże, s. 18. 
lecz w duchowym, pozaświatowym sensie ${ }^{57}$; i takim właśnie też Mesjaszem się mienił ${ }^{58}$.

Wreszcie Elia Benamozegh (1823-1900), Żyd sefardyjski, ortodoksyjny rabin, urodzony i żyjący we włoskim Livorno (jego rodzice pochodzili z Maroka), pozostawił po sobie kilkanaście dzieł, ważnych szczególnie w obszarze dialogu żydowsko-chrześcijańskiego. W książce Lorigine des dogmes chrétiens stwierdził, że Jezusa trzeba umieścić w szerokim kontekście esseńskim; doprecyzował jednak, że istnieje również „zadziwiająca zgodność znaczeniowa między Kabałą i chrześcijaństwem”59. Przecież „tylko w Zoharze, a ogólnie w Kabale, mówi się wzniośle o upersonifikowanym Słowie-Mesjaszu” ${ }^{0}$. Skoro celem Jezusa było „zbawienie Żydów”61, nie czerpał On zatem niczego z pogaństwa, lecz „zawsze czuł się bliski faryzeuszom”62, aczkolwiek rzekomo właśnie „W odmianie esseńsko-kabalistycznej" ${ }^{33}$.

Istnieje w XIX wieku także grupa żydowskich uczonych, którzy wprawdzie wspomnieli o Jezusie w swych dziełach, ale bardzo marginalnie, bez podjęcia głębszej próby usytuowania Go w konkretnym nurcie judaizmu; ograniczyli się oni w ten sposób do stwierdzenia jedynie Jego fałszywego mesjanizmu ${ }^{64}$.

57 Por. tamże, s. 19,

${ }_{58}$ Por. tamże, s. 20.

59 E. Benamozegh, Lorigine dei dogmi Cristiani, red. M.C. Morselli, Genova 2016 (pierwsze wydanie - 2002), s. 176.

60 Tamże, s. 240.

${ }^{61}$ Tamże, s. 30.

62 Tamże, s. 44.

63 Tamże, s. 45. Warto nadmienić, że Joseph Cohen (1917-1899), publicysta i znawca faryzeizmu, jeden $\mathrm{z}$ redaktorów pierwszego żydowskiego tygodnika w języku francuskim „La Vérité Israélite”, opublikował dzieło Les Déicides. Examen de la divinté de Jésus-Christ et de léglise chrétienne au point de vue du judaïsme (Bogobójstwa. Analiza Boskości Jezusa Chrystusa i Kościoła chrześcijańskiego z punktu widzenia judaizmu; Paris 1861), w którym podkreśla, że wszystkie rzekome znaki Boskości Jezusa działy się tylko wobec nielicznej grupy odbiorców, często także przy ich wątpieniu; samo zmartwychwstanie to nawet nie dokonało się przed jakimikolwiek ludzkimi oczami (s. 366).

${ }^{64}$ Por. Lady Magnus, Outlines of Jewish History. Completely Revised and Brought Up To 1948, London 1958, s. 29-31; S. Bäck, Geschichte des jüdischen Volkes und seiner Litaratur vom babylonischen Exile bis auf die Gegenwart, Frankfurt am Main 1906 (pierwsze wydanie - 1878), s. 134-137.); T. Kroner, Geschichte der Juden von Esra bis 


\section{PODSUMOWANIE I WNIOSKI}

Analizowane źródła pozwoliły na uchwycenie specyfiki początkowego okresu judaizmu naukowego, a mianowicie sprowadza się ona ogólnie do odzyskania żydowskości Jezusa poprzez lekturę, nie pozbawioną jeszcze pewnej rezerwy, Nowego Testamentu. Światlejszym Żydom sprzyjało w tym przedsięwzięciu trwające po stronie chrześcijańskiej (aczkolwiek niekatolickiej) tzw. pierwsze poszukiwanie Jezusa historycznego, rozpoczęte umownie pośmiertną publikacją pism Hermanna S. Reimarusa (zm. 1768), charakteryzujące się racjonalistycznym usuwaniem $\mathrm{z}$ ewangelii materiału rzekomo interpretacyjno-mitycznego (teologii pierwotnego Kościoła), by odnaleźć prawdziwego Jezusa. Na tym etapie badań nie istnieją jeszcze ściśle opracowane kryteria autentyczności słów i czynów Jezusa (co będzie domeną drugiego poszukiwania, w XX wieku), dlatego też do głosu dochodzi tutaj religijna wyobraźnia uczonych. Badacze żydowscy albo umieszczają Jezusa w obrębie judaizmu peryferyjnego, częściowo nawet jakby heretyckiego (esseńskiego), albo mają już na tyle odwagi, by związać Go z najważniejszym nurtem ówczesnego judaizmu, czyli faryzeizmem. W konsekwencji minimalizują udział strony żydowskiej w doprowadzeniu do śmierci Jezusa, zrzucając główną odpowiedzialność za Jego ukrzyżowanie na polityczne barki pogańskiego namiestnika.

Spojrzenie świata naukowego na esseńczyków znacząco wzbogaciło się po odkryciu w połowie XX wieku w Chirbet/Khirbet Qumran, na północno-zachodnim wybrzeżu Morza Martwego, ponad 850 rękopisów, należących właśnie do tego ruchu. Qumrańczycy uważali się za prawdziwą resztę Izraela żyjącego na końcu czasów w oczekiwaniu na zwycięstwo Boga w wojnie eschatologicznej ${ }^{65}$. Żaden fragment ze zwojów qumrańskich nie został napisany ręką chrześcijanina; nigdy też sam Jezus nie jest w nich wzmiankowany. Zdaniem dzisiejszych uczonych, mógł On jednak znać ruch esseński ${ }^{66}$

zur Jetztzeit, für Volksschulen und höhere Lehranstalten, wyd. II, Frankfurt a. M. 1899, s. 28); D. Cassel, Lehrbuch der jüdischen Geschichte und Literatur, Leipzig 1879, s. 120.

${ }^{65}$ Por. M. Parchem, Ostateczne zwycięstwo Boga w walce między dobrem a złem w świetle pism z Qumran, Warszawa 2008, s. 480-481.

${ }^{66}$ Por. M. Rosik, Kościół a Synagoga (30-313 po Chr.) na rozdrożu, Wrocław 2016, s. 239. 
czy nawet pozostawać pod jego wpływem ${ }^{67}$, aczkolwiek sam z pewnością nie przeszedł kilkuletniego „cyklu inicjacji”"68. James H. Charlesworth (metodysta) wskazuje 24 paralele między Qumrańczykami i Jezusem ${ }^{69}$ oraz 27 rozbieżności ${ }^{70}$. Uwzględniając niejako hipotezy tych różnych uczonych, Joseph Ratzinger/Benedykt XVI napisał: „Wydaje się, że Jan Chrzciciel, a może nawet sam Jezus i Jego rodzina byli blisko tej wspólnoty. [...] Nie można wykluczyć, że Jan Chrzciciel przez pewien czas żył w tej wspólnocie i ona też po części ukształtowała jego religijną postawę"71. A zatem, ostatecznie, nie ma poważnych argumentów przemawiających za esseńską tożsamością Jezusa.

Jeśli natomiast chodzi o faryzeizm, to sprawa była żywo dyskutowana zarówno w drugiej, jak i w trzeciej fazie (Third Quest) poszukiwania Jezusa historycznego (np. H. Falk, zm. 2008 ${ }^{72}$; H. Maccoby, zm. 200473). Wybitny uczony żydowski David Flusser (zm. 2000) uważał ogólnie, że nie byłoby błędem „opisać Jezusa jako faryzeusza w sensie szerokim”74. Tym razem jednak można odwołać się niejako do „świadka koronnego”, a mianowicie św. Pawła, który sam przyznawał się do faryzeizmu (por. Flp 3,5: „W stosunku do Prawa - faryzeusz”), a nigdy nie próbował pochwalić się, że „tak jak Jezus”. Między nauczaniem Jezusa i nauczaniem faryzeuszy istnieją również istotne różnice, które doprowadziły późniejszych rabinów, będących spadkobiercami tego właśnie ugrupowania, do radykalnej separacji judaizmu talmudycznego od pierwotnego chrześcijaństwa. Joseph Ratzinger/Benedykt XVI pisał: „Ja Jezusa wypowiedziane jest $\mathrm{z}$ takim autorytetem, na jaki nie może sobie pozwolić żaden uczony w Piśmie. [...] Zatem

${ }^{67}$ Por. J.H. Charlesworth, The Dead Sea Scrolls and the Historical Jesus, w: Jesus and the Dead Sea Scrolls, red. tenże i in., London 1992, s. 37-38.

${ }^{68}$ H. Stegemann, Esseńczycy z Qumran, Jan Chrzciciel i Jezus, tłum. Z. Małecki i A. Tronina, Kraków-Mogilany 2002, s. 301.

${ }^{69}$ Por. J.H. Charlesworth, The Dead, s. 9-22.

${ }^{70}$ Por. tamże, s. 22-35.

${ }^{71}$ J. Ratzinger/Benedykt XVI, Jezus $z$ Nazaretu, cz. I: Od chrztu $w$ Jordanie do Przemienienia, tłum. W. Szymona, Kraków 2007, s. 26-27.

${ }^{72}$ Por. H. Falk, Jesus the Pharisee. A New Look at the Jewishness of Jesus, Eugene 2003, s. $115-129$.

73 Por. H. Maccoby, Jesus the Pharisee, London 2003, s. 39.

74 D. Flusser, The Sage from Galilee. Rediscovering Jesus' Genius, Grand Rapids - Cambridge 2007 (IV wyd.), s. 47. 
albo targnął się na Boski Majestat, co byłoby straszne, ale też - co wydaje się nie do pojęcia - rzeczywiście dorównuje wielkością Bogu"75. Teologia chrześcijańska wypowiada się wyraźnie o Boskiej tożsamości Jezusa.

W ostatnich latach pogłębiła się także wiedza naukowa na temat barw mesjańskich Jezusa, przyczyniających się ostatecznie do Jego śmierci. Pozostawiając na boku przekonania niezwykle licznych dzisiaj Żydów mesjanicznych ${ }^{76}$, należy tylko wspomnieć choćby Daniela Boyarina (ur. 1946 w USA), Żyda ortodoksyjnego (konserwatywnego), który tezę, że Mesjasz miał być Bosko-ludzki, traktuje jako „nieodłączną część tradycji żydowskiej"77.

Nietrudno zatem na koniec skonstatować, że europejscy uczeni żydowscy XIX wieku odkryli w Nowym Testamencie swoje duchowe dziedzictwo. To był naprawdę ten ich „pierwszy krok” poczyniony zupełnie dobrowolnie, aczkolwiek jeszcze ze swoistą metodologiczną i religijną rezerwą, w kierunku chrześcijaństwa, a szczególnie ku żydowskiemu Jezusowi. I chociaż księgi Nowego Testamentu nie stały się jeszcze dla tych Żydów, oczywiście, nowym świadectwem wiary, to jednak uznali oni je już przynajmniej za źródła godne dalszych badań naukowych. W ten sposób został niejako wyznaczony całkowicie nowy początek w dialogu chrześcijańsko-żydowskim.

\section{BIBLIOGRAFIA}

[Anonimowo], The Existence of Christ Disproved By Irresistible Evidence, In A Series of Letters, From A German Jew. [30 Letters]. Jesus Christ, London [bez roku wydania].

Bäck S., Geschichte des jüdischen Volkes und seiner Litaratur vom babylonischen Exile bis auf die Gegenwart, Frankfurt am Main 1906.

Benamozegh E., L'origine dei dogmi Cristiani, red. M.C. Morselli, Genova 2016.

Biographisches Handbuch der Rabbiner, red. M. Brocke, J. Carlebach, Teil 1: Die Rabbiner der Emanzipationszeit in den deutschen, böhmischen und großpolnischen Ländern 1781-1871, red. C. Wilke, München 2004, s. 386-388.

75 J. Ratzinger/Benedykt XVI, Jezus, s. 95.

${ }^{76}$ Np. zob. D.H. Stern, Messianic Judaism. A Modern Movement with an Ancient Past, Clarksville 2007.

${ }_{77}$ D. Boyarin, The Jewish Gospels. The Story of the Jewish Christ, New York 2012, s. 56. 
Boyarin D., The Jewish Gospels. The Story of the Jewish Christ, New York 2012.

Cassel D., Lehrbuch der jüdischen Geschichte und Literatur, Leipzig 1879.

Charlesworth J.H., The Dead Sea Scrolls and the Historical Jesus, w: Jesus and the Dead Sea Scrolls, red. tenże i in., London 1992, s. 1-74.

Cohen J. Les Déicides. Examen de la divinté de Jésus-Christ et de l'église chrétienne au point de vue du judaïsme, Paris 1861.

Derenbourg J., Essai sur l'Histoire et la Géographie de la Palestine, d'après les Thalmuds et les autres sources rabbiniques, I: Histoire de la Palestine depuis Cyrus Jusquà Adrien, Paris 1867.

Duschak M., Die Moral der Evangelien und des Talmuds: eine vergleichende Studie im Geiste unserer Zeit, Brünn 1877.

Ettinger S., Pyka M., Graetz, Heinrich, w: Encyclopaedia Judaica, red. F. Skolnik, M. Berenbaum, Detroit i in. 2007, wyd. II, t. 8, s. 26-29.

Falk H., Jesus the Pharisee. A New Look at the Jewishness of Jesus, Eugene 2003.

Flusser D., The Sage from Galilee. Rediscovering Jesus ' Genius, Grand Rapids-Cambridge 2007, wyd. IV.

Geiger A., Das Judenthum und seine Geschichte. In zwölf Vorlesungen, Breslau 1864.

Glatzer N.N., Pelger G., Zunz, Leopold, w: Encyclopaedia Judaica, red. F. Skolnik, M. Berenbaum, Detroit i in. 2007, wyd. II, t. 21, s. 684-688.

Graetz H., Historja Żydów, tł. S. Szenhak, Warszawa 1929, t. I-II-III.

Grünebaum E., Die Sittenlehre des Judenthums Anderen Bekanntnissen Gegenüber Nebst dem Geschichtlichen Nachweise über Enstehung des Pharisäismus und Dessen Verhältnis zum Stifter der Christlichen Religion, Mannheim 1867.

Güdemann M., Nächstenliebe. Ein Beitrag zur Erklärung des Matthäusevangeliums, Wien 1890.

Hamburger J., Jesus von Nazaret. Geschichtliche, objektive Darstellung seines Lebens, Wirkens und Todes, Berlin 1895.

Heschel S., Abraham Geiger and the Jewish Jesus, Chicago 1998.

Hess M., Rom und Jerusalem, Leipzig 1899, wyd. II.

Hirsch S., Die Religionsphilosophie der Juden oder das Prinzip der jüdischen Religionsanschauung und sein Verhältni $\beta$ zum Heidenthum, Christenthum und zur absoluten Philosophie dargestellt und mit erläuterten Beweisstellen aus der heiligen Schrift, den Talmudim und Midraschim versehen, Leipzig 1842.

Joël M., Blicke in die Religionsgeschichte zu Anfang des zweiten christlichen Jahrhunderts mit Berücksichtigung der angränzenden Zeiten. II. Abtheilung: Der Conflict des Heidenthums mit dem Christenthume in seinem Folgen für das Judenthum, Breslau 1883.

Jost I.M., Geschichte der Israeliten seit der Zeit der Maccabäer bis auf unsere Tage nach den Quellen bearbeitet, t. I, Berlin 1820.

Jost I.M., Geschichte des Judenthums und seiner Sekten, t. I, Leipzig 1857.

Kroner T., Geschichte der Juden von Esra bis zur Jetztzeit, für Volksschulen und höhere Lehranstalten, wyd. II, Frankfurt am Main 1899. 
Kulisher M., Das Leben Jesu eine Sage von dem Schicksale und Erlebnissen der Bodenfrucht, insbesondere der sogenannten palästinensischen Erstlingsgarbe, die am Passahfeste im Tempel dargebracht wurde, Leipzig 1876.

Maccoby H., Jesus the Pharisee, London 2003.

Magnus, Lady, Outlines of Jewish History. Completely Revised and Brought Up To 1948, London 1958.

Parchem M., Ostateczne zwycięstwo Boga $w$ walce między dobrem a złem w świetle pism z Qumran, Warszawa 2008.

Philippson L., Die Entwickelung der religiösen Idee im Judenthume, Christenthume und Islam: in zwölf Vorlesungen über Geschichte und Inhalt des Judenthums dargestellt, Leipzig 1847.

Philippson L., Haben wirklich die Juden Jesum gekreuzigt?, Leipzig 1901.

Pyka M., Jost, Isaac Marcus, w: Encyclopaedia Judaica, t. 11, red. F. Skolnik, M. Berenbaum, Detroit i in. 2007, wyd. II, s. 463-464.

Rabbinowicz J.M., Le role de Jésus et des apotres, Bruxelles 1866.

Ratzinger J./Benedykt XVI, Jezus z Nazaretu, cz. I: Od chrztu w Jordanie do Przemienienia, tłum. W. Szymona, Kraków 2007.

Rodrigues H., Les Origines du Sermon de la Montagne, Paris 1868.

Rodrigues H., Le Roi des Juifs, Paris 1870.

Rosik M., Kościół a Synagoga (30-313 po Chr.) na rozdrożu, Wrocław 2016.

Saalschütz J.L., Zur Versöhnung der Confessionen, oder Judenthum und Christenthum, in ihrem Streit und Einklang, Königsberg 1844.

Saalschütz J.L., Das Mosaische Recht nebst der vervollständigenden thalmudisch-rabbinischen Bestimmungen. Für Bibelforscher, Juristen und Staatsmänner, Berlin 1853.

Salvador J., Jesus-Christ et sa doctrine: histoire de la naissance de l'église, de son organisation et de ses progrès pendant le premier siècle, t. I-II, Paris 1838.

Soloweyczyk E., Harvq Lvq Kol Koré (Vox clamantis). La Bible, le Talmud et l'Évangile. Évangile de Mathieu, Paris 1875.

Stegemann H., Esseńczycy z Qumran, Jan Chrzciciel i Jezus, tłum. Z. Małecki i A. Tronina, Kraków-Mogilany 2002.

Stern D.H., Messianic Judaism. A Modern Movement with an Ancient Past, Clarksville 2007.

Weill A.A., Moïse, le Talmud et l'Évangile, Paris 1891.

Zipser M., The Sermon on the Mount Reviewed in an Essay on the Talmud and the Gospels, London 1852. 